\title{
Intergovernmental Dalam Penanganan Bencana Alam Di Pemerintahan Daerah
}

\author{
Anwar Sadat \\ Ilmu Pemerintahan Universitas Muhammadiyah Buton \\ Email: anwarsadat685@gmail.com
}

\begin{abstract}
Abstrak, Semangat desentralisasi merubah paradigma penanganan bencana dengan lebih memberikan ruang kewenangan kepada pemerintah daerah untuk memanage bencana di daerahnya. Namun tantangan besarnya adalah menyamakan persepsi masing masing pemerintah daerah bahwa penanganan bencana alam di daerah tidak bisa dikelola oleh satu institusi/pemerintahan daerah berdasar tapal batas administrasi. Penelitian ini menggunakan metode pendekatan induktif yang memungkinkan untuk mendiskripsikan hasil berbagai Kajian analisis kemungkinan upaya kerjasana antar daerah. Hasil beberapa kajian tentang penanganan bencana murujuk kesimpulan bahwa upaya penganganan pra, bencana dan pasca bencana sangat multidimensional. Dalam konteks kewenangan pemerintahan, penanganan bencana tidak hanya dilakukan oleh satu pemerintah daerah saja. Dengan begitu, kerjasama antar daerah (intergovernmental networks) penting dikembangkan pada tingkatan daerah. Kerjasama antar daerah sangat berpotensi untuk mendorong kapasitas pemerintah daerah dalam rangka sharing penglaman, sharing keuntungan dan sharing tugas/beban secara bersama sama dalam peningkatan fungsi pelayanan publik setiap pemerintah daerah. Hasil kajian juga menyimpulkan pentingnya penguatan lembaga BPBD untuk memudahkan kerjasama antar pemerintahan di daerah dalam penanggulangan bencana.
\end{abstract}

Kata Kunci: Kerjasama, Daerah, Bencana

\begin{abstract}
The spirit of decentralization has changed the paradigm of handling disasters by giving more space to authorities to manage disasters in their regions. But the big challenge is to equalize the perceptions of each local government that handling natural disasters in the regions cannot be managed by one institution/regional government based on administrative boundaries. This study uses the inductive approach method that allows to describe the results of various studies analysis of the possibility of cooperation between regions. The results of several studies on disaster management have come to the conclusion that efforts for pre, disaster and post-disaster handling are very multidimensional. In the context of government authority, disaster management is not only carried out by one local government. Thus, intergovernmental networks are important to be developed at the regional level. Collaboration between regions has the potential to encourage the capacity of local governments to share experience, share profits and share tasks/burdens together in improving the function of public services for each local government. The results of the study also concluded the importance of strengthening BPBD institutions to facilitate cooperation between governments in the regions in disaster management.
\end{abstract}

Keyword: Cooperation, Regional, Disaster 


\section{Pendahuluan}

Indonesia secara geografis merupakan kepulauan yang terletak pada pertemuan empat lempeng tektonik, yaitu lempeng Benua Asia, lempeng Benua Australia, lempeng Samudera Hindia dan lempeng Samudera Pasifik. Pada bagian selatan dan timur Indonesia terdapat sabuk vulkanik (volcanic arc) yang memanjang dari Pulau Sumatera-Jawa-Nusa Tenggara-Sulawesi, yang sisinya berupa pegunungan vulkanik tua dan dataran rendah yang sebagian didominasi oleh rawa-rawa. Data menunjukkan bahwa Indonesia merupakan salah satu negara yang memiliki risiko gempa bumi yang tinggi di dunia, lebih dari 10 kali lipat risiko gempa bumi di Amerika Serikat (Arnold, 2014). Selain itu, iklim tropis dengan dua musim, yaitu panas dan hujan dengan ciri adanya perubahan cuaca, suhu dan arah angin yang cukup ekstrim. Kondisi iklim seperti ini digabungkan dengan kondisi topografi permukaan dan batuan yang relatif beragam, baik secara fisik maupun kimiawi, menghasilkan kondisi tanah yang subur. Sebaliknya, kondisi itu dapat menimbulkan beberapa akibat buruk bagi manusia seperti terjadinya bencana hidrometeorologi seperti banjir, tanah longsor, kebakaran hutan dan kekeringan. Seiring dengan berkembangnya waktu dan meningkatnya aktivitas manusia, kerusakan lingkungan hidup cenderung semakin parah dan memicu meningkatnya jumlah kejadian dan intensitas bencana hidrometeorologi (banjir, tanah longsor dan kekeringan) yang terjadi secara silih berganti di banyak daerah di Indonesia.

Selama kurun waktu 1600-2000 terdapat 105 kejadian tsunami yang 90 persen di antaranya disebabkan oleh gempa tektonik, sembilan persen oleh letusan gunung berapi dan satu persen oleh tanah longsor. Wilayah pantai di Indonesia merupakan wilayah yang rawan terjadi bencana tsunami terutama pantai barat Sumatera, pantai selatan Pulau Jawa, pantai utara dan selatan pulau-pulau Nusa Tenggara, pulau-pulau di Maluku, pantai utara Irian Jaya dan relatif seluruh pantai di Sulawesi. Laut Maluku adalah daerah yang paling rawan tsunami. Dalam kurun waktu tahun 1600-2000, di daerah ini telah terjadi 32 tsunami yang 28 di antaranya diakibatkan oleh gempa bumi dan 4 oleh meletusnya gunung berapi di bawah laut (BNPB, 2014). 
Model penanganan bencana alam pada masa lalu ( orde baru ) masih menggunakan sistem birokrasi hirarkial yang kaku dan sentralistik, memang semua kebijakan yang terkait dengan pengelolaan bencana bisa dijalankan tanpa ada kendala yang berarti. Tentu saja model penanganan tersebut memiliki kelemahan, salah satunya adalah penanganan yang kurang tepat sasaran karena pemerintah dan masyarakat setempat kurang dilibatkan. Berakhirnya rezim orde baru dan memasuki era reformasi, kebijakan desentralisasi dan otonomi daerah yang lebih nyata mulai diwujudkan, terjadi pergeseran pola hubungan pusat daerah yang semula bersifat hirarkial berubah menjadi relatif otonom. Perubahan pola hubungan tersebut, berimplikasi pada perubahan strategi dan konsep pengelolaan bencana di daerah.

Semangat desentralisasi yang dipraktikan dalam otonomi daerah saat ini membuat peran pemerintah pusat yang semakin berkurang serta kemungkinan adanya resistensi daerah ditambah dominannya pemerintah daerah seakan menjadi tantangan. Selain itu, bagaimana mencetak road map penanganan bencana daerah yang memiliki dampak luas dan lintas sektoral serta melibatkan banyak aktor di dalamnya. Berdasarkan kondisi tersebut, perlu pemikiran untuk mencoba memaparkan pengelolaan bencana daerah dalam perspektif kerjasama antar daerah (intergovermental) dengan skema network governance. Pemikiran ini sekaligus memberikan penegasan bahwa dalam penanganan bencana alam di daerah tidak bisa dikelola oleh satu institusi/pemerintahan atau aktor tunggal ataupun dikelola dengan cara membagi berdasar tapal batas administrasi, namun oleh beberapa lapis pemerintahan berbasis intergovernmental networks.

Implikasi dari penguatan pendekatan desentralisasi dalam pola hubungan pemerintahan dengan pemerintah daerah salah satunya adalah pemerintah lokal merasa memiliki kewenagan otonom dalam mengelola daerahnya termasuk dalam hal penanganan bencana. Kelanjutanya adalah semakin melemahnya kordinasi antar daerah yang dulunya pernah intensif dimotori oleh propinsi. Keberadaan Badan Penanggulangan Bencana Daerah (BPBD) belum lengkap diseluruh kabupaten dan kota di 
Indonesia. Kondisi tersebut menyulitkan BPBD Propinsi, BPBD Kabupaten dan Kota dalam penanganan dan pengelolaan bencana suatu daerah. karena bencana alam di suatu daerah sejatinya tidak dapat meningggalkan peran daerah sekitar terlebih terkait dengan isu-isu lingkungan dan bencana yang memiliki dampak luas dan melewati batas wilayah administrasi. Sehingga dua hal penting yang akan didialogkan dalam paper adalah : a). Bagaimana urgensi KAD dalam penangangan Bencana di daerah, dan b). Sejauhmana perubahan reposisi peran kelembagaan dalam penaganan bencana di daerah.

\section{Metode Penelitian}

Artikel ini menggunakan metode penelitian kualitatif deskriptif dengan pendekatan studi kasus. Pendekatan secara deskriptif dimaksudkan untuk melakukan penggambaran terhadap fenomena sosial /kasus tertentu yang bertujuan untuk membuat deskripsi, gambaran secara sistematis, faktual dan akurat mengenai fakta serta hubungan antar fenomena. Penulisan paper ini bersumber dari data berbagai penelitian studi implementasi kebijakan yang hasilnya disajikan secara deskriptif.
Kajian akan menganalisis kemungkinan upaya kerjasama antar daerah dalam penanggulangan bencana di daerah yang dilakukan dengan cara mengetahui standart dan sasaran kebijakan/program/kegiatan, kondisi sumber daya, dan kondisi sosial politik dan ekonomi.

Setelah ketiga hal tersebut diketahui secara pasti, hal selanjutnya yang perlu dieksplorasi adalah karakteristik kelembagaan dan komunikasi antar organisasi yang dilakukan dalam memaksimalkan pelaksanaan penanggulangan bencana di daerah. Explorasi data dalam penulisan ini bersumber pada penelitian yang dilakukan oleh tim peneliti Badan Penelitian dan Pengembangan Kota Baubau berkerjasa dengan Universitas Muhammadiyah Buton tentang Kajian Kelembagaan dan Regulasi Penanggulangan Bencana di Kota Baubau.

Analisis data kualitatif dalam penelitian ini dilakukan dengan metode induktif, yaitu suatu analisis berdasarkan data yang diperoleh, selanjutnya dikembangkan pola hubungan tertentu, selanjutnya dicarikan data lagi secara berulangulang sehingga selanjutnya dapat dapat 
dibuat kesimpulan yang bersifat umum. Hal tersebut sejalan dengan pernyataan Sugiono (2003) yang menyatakan bahwa "Penelitian kualitatif tidak dimulai dari deduksi teori, tetapi dimulai dari lapangan yakni fakta empiris. Peneliti terjun ke lapangan, mempelajari suatu proses atau penemuan yang tenjadi secara alami, mencatat, menganalisis, menafsirkan dan melaporkan serta menarik kesimpulan-kesimpulan dari proses tersebut".

\section{Hasil Penelitian}

Penguatan aspek desentralisasi daripada sentralisasi dalam pola pemerintahan di indonesia pasca reformasi di wujudkan dalam konsep otonomi daerah yang lebih faktual baik dalam UU 22 tahun 1999 dan kemudian di sempurnakan dengan UU 32 tahun 2004 maupun UU No 23 tahun 2014. Pilihan desentralisasi yang dipraktekan dalam otonomi daerah sejatinya mengandung harapan lahirnya perbaikan dalam berbagai dimensi pemerintahan, baik dalam tatakelola pemerintahan, perbaikan dan peningkatan kualitas pelayanan masyarakat di daerah serta penguatan demokrasi local dan aspek lainnya.
Harapan baik dari parktek desentralisasi tesebut setidaknya pernah didengungkan oleh BC. Smith (1985:19-29) yang memberikan arah tujuan dari pilihan praktek desentralisasi yaitu: a). Pendidikan Politik, b). Latihan Kepemimpinan politik, c). Stabilitas Pilitik, d).Kesamaan Politik, e). Akuntabilitas, f). Daya tanggap (responsibility) dan g). Efisiensi dan Efektifitas bagi pemerintahan daerah/lokal.

Disisi lain, desentralisasi dalam wujud otonomi daerah sebagai sebuah pilihan selain membawa konsekuensi praktek positif (best practice), pun memungkinka terjadinya praktek pemerintahan yang buruk/negative (bad Practice) dari berbagai aspek pemerintahan di daerah. Terkait dengan kondisi tersebut, Ekoprasodjo dkk. dalam penelitianya

memberikan gambaran bahwa:

" praktik desentralisasi dan otonomi daerah sejak tahun 2001 tidak sepi dari kritik. Beberapa kritik tersebut diantaranya adalah: (1) masalah yang berkaitan dengan penyalahgunaan kekuasaan yang ditandai dengan korupsi "berjamaah" di berbagai propinsi, kabupaten dan kota. Bukan hanya modus operandinya yang berkembang, tetapi juga pelaku, jenis dan nilai yang dikorupsi juga menunjukkan tingkatan yang lebih variatif dan intensif dari masa-masa 
sebelum otonomi diberlakukan. (2) persoalan yang berkaitan dengan pengelolaan sumber daya alam (SDA) yang tidak terkontrol. Seringkali atas nama Pendapatan Asli Daerah (PAD), eksploitasi sumber daya alam berlangsung secara masif dan tidak memenuhi pertimbangan pembangunan berkelanjutan. Alokasi kebijakan anggaran lebih banyak digunakan untuk belanja aparatur daripada belanja publik. pembangunan yang semakin tidak terkendali karena buruknya hubungan antar pemerintah pusat, propinsi dan kabupaten/kota. Keterpaduan pembangunan secara regional dan nasional seringkali macet akibat dari egoisme lokal. (4) persoalan hubungan antara legislatif dan eksekutif yang sering menyebabkan ketegangan dan ketidakharmonisan dalam penyelenggaraan pemerintahan daerah".

Dampak positif maupun negative yang timbul dari pergeseran paradigma kebijakan pemerintahan dari sentralistis menuju desentralistis merupakan hal yang lazim terjadi. Dengan demikian, ketika infrastruktur Negara merubah suprastruktur Negara dengan meregulasi kebijakan untuk menyesuaikan dengan kebutuhan pendekatan desentralisasi, maka dampak praktek positip pemerintahan di daerah dan praktik negatif pemerintahan di daerah akan terjadi sebagai bagian dari proses peralihan paradigma. Fakta sementara saat ini, konsep desentralisasi dan Otonomi Daerah diartikulasikan oleh Daerah hanya terfokus pada usaha menata dan mempercepat pembangunan di wilayahnya masing- masing. Tafsir seperti ini ternyata belum cukup efisien dalam meningkatkan pelayanan kepada masyarakat, karena tidak dapat dipungkiri bahwa maju mundurnya suatu daerah juga terdapat faktor pengaruh dari daerah-daerah lainnya, khususnya daerah yang berdekatan/bertetangga.

Salah satu pendekatan yang paling mengemuka adalah pendekatan jaringan (networking). Ketika networks sudah terbangun, tantangan selanjutnya adalah bagaimana strategi dalam mengelola networks tersebut. Pendekatan Jaringan mendasarkan pada asumsi bahwa relasi para aktor itu bersifat saling tergantung satu sama lain (interdependence). Dalam makna yang lebih operasional, aktor tidak bakal mampu mencapai tujuantujuannya tanpa menggunakan sumberdaya-sumberdaya yang dimiliki oleh aktor lain. Dengan kata lain hubungan ini menghendaki adanya pertukaran sumberdaya-sumberdaya yang ada dalam jaringan (Rhodes dan Marsh, 1992; Rodes, 1997 dalam 
Pratikno, 2008). Pola jaringan ini semakin lama akan semakin menjadi kompleks jika dilihat dari sumberdaya yang ditukar dan daya tawar para aktornya.

Adanya kekakuan dalam pengelolaan hubungan antar pemerintah tersebut maka perlu dicari jalan keluar untuk mendobrak hubungan yang semula berbasis paksaan, hirarkis dan legal formal serta bertujuan membangun sinergi yang baik antar pemerintah daerah serta antar pemerintah daerah dan pusat, yaitu dengan intergovernmental networks (Pratikno,2007). Intergovernmental networks pada tingkatan daerah sangat berpotensi untuk mendorong kapasitas pemerintah daerah dalam rangka peningkatan fungsi pelayanan publik bagi setiap pemerintah daerah. Pada level pemerintahan, seperti di ataur dalam Peraturan pemerintah No. 50 tahun 2007 disebutkan bahwa kesepakatan Kerjasama antar daerah dapat dilakukan antara Pemerintah Propinsi dengan Pemerintah Propinsi lain, Propinsi dengan pemerintah Kabupaten/Kota dan atau antar Pemerintah Kabupaten/kota dengan pemerintah Kabupaten/Kota.
Dalam Konteks pendanaan sebagaimana dikutip dari kajian yang dilakukan oleh Tim Peneliti Balitbang dan Akademisi, menggambarkan bahwa Risiko bencana yang relatif kecil, sering terjadi dan dapat diprediksi seperti banjir, longsor dan kekeringan dapat dibiayai dari sumber-sumber dana cadangan yang dianggarkan secara rutin. Sedangkan untuk mengantisipasi risiko bencana besar seperti gempa bumi dan tsunami, maka kombinasi antara penyiapan dana siaga yang diakumulasi dari pencadangan dari anggaran secara rutin (dan dikelola di luar anggaran), serta adanya penggunakan sumber pembiayaan bencana diluar anggaran seperti skema asuransi bencana menjadi sesuatu yang sangat penting. Risiko bencana yang relatif kecil, sering terjadi dan dapat diprediksi seperti banjir, longsor dan kekeringan dapat dibiayai dari sumber- sumber dana cadangan yang dianggarkan secara rutin. Hal ini sekaligus sebagai bentuk kemitraan Pemerintah dan Pemeritah Daerah dengan pihak swasta dalam mengalihkan sebagian risiko ke pasar keuangan. Dalam kerangka ini pengembangan strategi pembiayaan risiko serta asuransi risiko bencana merupakan bagian dari agenda utama 
pembangunan dan Penanggulangan Bencana. Bagian penting dari upaya penanggulangan bencana di indonesia adalah penataan kelembagaan penanganan bencana alam. Harapan besar dengan adanya penataan kelembagaan penanganan bencana di daerah adalah terjalin komunikasi dan kerjasama pembagian tugas dalam menangani bencana. Regulasi kelembagaan penanggulangan bencana di Indonesia diatur oleh UndangUndang Nomor 24 tahun 2007 tentang Penanggulangan Bencana. Mengacu pada peraturan di atas telah dibentuk kelembagaan formal di tingkat pusat yaitu Badan Nasional Penanggulangan Bencana (BNPB) sebagai pengganti dari Bakornas PB melalui Perpres Nomor 8 Tahun 2008. BNPB terdiri dari unsur pengarah dan unsur pelaksana penanggulangan bencana. Unsur Pengarah terdiri dari sepuluh anggota yang diwakili oleh pejabat eselon 1 dari instansi terkait dan Sembilan anggota masyarakat profesional. Adanya unsur pengarah dan pelaksana dalam BNPB mencerminkan penyelenggaraan PB yang melibatkan semua pemangku kepentingan.

Di tingkat Pemerintah Daerah, reformasi kelembagaan PB didasarkan pada Peraturan Menteri Dalam Negeri Nomor 46 Tahun 2008 dan Peraturan Kepala BNPB Nomor 3 Tahun 2008. Badan Penanggulanan Bencana Daerah (BPBD) provinsi maupun BPBD Kabupaten/Kota dibentuk menggantikan kelembagaan Penanggulanan Bencana yang selama ini bersifat ad hoc. Menurut UndangUndang tersebut, di setiap Provinsi dan Kabupaten/Kota dibentuk Badan Penanggulangan Bencana dan dilengkapi dengan Peraturan Daerah tentang Penanggulangan Bencana. Artinya Undang-Undang ini mengamanahkan bahwa di daerah, terdapat lembaga khusus yang menangani penanggulangan bencana yaitu Badan Penanggulangan Bencana Daerah (BPBD). BPBD dibentuk baik di tingkat provinsi maupun Kabupaten/Kota. Seperti juga BNPB di tingkat pusat, di daerah BPBD bertugas untuk merumuskan dan menetapkan kebijakan Penanggulangan Bencana dan penanganan pengungsi serta melakukan pengoordinasian pelaksanaan kegiatan PB.

\section{Pembahasan}

Kerjasama Antar Daerah: Sebagai Upaya Memperkuat 
Kelembagaan Penanganan Bencana Daerah

Pada kurun waktu belakangan ini, penanggulangan bencana secara umum telah mengalami perubahan paradigma yang amat mendasar, yaitu dari penanganan bencana yang sifatnya responsif-kuratuf berubah menjadi pengurangan risiko bencana yang bersifat antisipatif-prefentif. Pendekatan tersebut memiliki makna bahwa penyelenggaraan penanggulangan bencana lebih menitikberatkan pada tahap pra bencana daripada tahap tanggap darurat (Haryati, 2013). Kesiapsiagaan terhadap bencana ini harus dapat diantisipasi baik oleh unsur pemerintah, swasta (dunia usaha) maupun masyarakat.

Terjadinya pergeseran paradigma penanggulangan bencana menjadi dasar bagi Pemerintah, Pemerintah Daerah, dunia usaha dan masyarakat untuk meningkatkan perhatian pada upaya antisipatif-prefentif, yaitu kegiatan pencegahan, mitigasi bencana, kesiapsiagaan, dan pemberian peringatan dini; seiring dengan kegiatan lain pada tahap tanggap darurat dan pemulihan yang bersifat responsif-kuratif. Undang- undang
Nomor 24 tahun 2007 tentang Penanggulangan Bencana mendefinisikan bencana sebagai peristiwa atau rangkaian peristiwa yang mengancam dan mengganggu kehidupan dan penghidupan masyarakat yang disebabkan, baik oleh faktor alam dan/atau faktor nonalam maupun faktor manusia sehingga mengakibatkan timbulnya korban jiwa manusia, kerusakan lingkungan, kerugian harta benda, dan dampak psikologis.

Merujuk pada Undang-undang Nomor 24 Tahun 2007 tentang Penanggulangan Bencana, kegiatan pencegahan bencana adalah serangkaian kegiatan yang dilakukan sebagai upaya untuk menghilangkan dan/atau mengurangi ancaman bencana (Pasal 1 ayat 6). Pencegahan merupakan suatu upaya preventif dalam mengelola ancaman dan kerentanan dari risiko bencana yang tertuang dalam program-program di masyarakat di tingkat lokal maupun daerah di tingkat kabupaten untuk menghilangkan secara total ancaman dan kerentanan penyebab risiko bencana. Adapun mitigasi bencana adalah serangkaian upaya untuk mengurangi risiko bencana, baik melalui pembangunan 
fisik maupun penyadaran dan penanggulangan bencana yang peningkatan kemampuan dalam mengemukakan peran menghadapi bencana (Pasal 1 ayat 9), Pemerintah/Pemerintah Daerah dengan kata lain baik mitigasi struktural maupun non struktural. Kegiatan mitigasi bertujuan untuk meminimalisasi dampak ancaman; dalam tahapannya kegiatan mitigasi dilakukan ketika kita telah melakukan identifikasi ancaman dengan programprogram yang diprioritaskan untuk mengelola ancaman. Kesiapsiagaan adalah serangkaian kegiatan yang dilakukan untuk mengantisipasi bencana melalui pengorganisasian serta melalui langkah yang tepat dan berdaya guna (Pasal 1 Ayat 7). Kemudian peringatan dini adalah serangkaian kegiatan pemberian peringatan sesegera mungkin kepada masyarakat tentang kemungkinan terjadinya bencana pada suatu tempat oleh lembaga yang berwenang (Pasal 1 Ayat 8).

Dengan demikian, telah terjadi perubahan paradigma penanggulangan bencana, yang sekurang- kurangnya terkait dengan 3 (tiga) perspektif perubahan, meliputi : (1) perubahan dari penanggulangan becana yang sifatnya responsif-kuratif menjadi bersifat antisipatif-preventif, (2) dari menjadi adanya peran bersama antara Pemerintah/Pemerintah Daerah, dunia usaha dan masyarakat, (3) dari penanggulangan bencana yang medasarkan pada konsepsi manajemen risiko menjadi pengurangan risiko. Sehingga perlu dipahami juga bahwa kegiatan penanggulangan bencana mencakup seluruh aspek kegiatan yang meliputi aspek perencanaan dan penanggulangan bencana pada sebelum terjadi, saat terjadi dan sesudah terjadi bencana yang dirancang untuk memberikan kerangka bagi orang perorangan atau komunitas yang berisiko terkena bencana untuk menghindari risiko, mengendalikan risiko, mengurangi risiko, menanggulangi maupun memulihkan diri dari dampak bencana. Penyelenggaraaan penanggulangan bencana, karenanya, merupakan serangkaian upaya yang meliputi penetapan kebijakan pembangunan yang berisiko timbulnya bencana, kegiatan pencegahan bencana, tanggap darurat, rehabilitasi dan rekonstruksi.

$$
\text { Kompleksitas penangangan }
$$
bencana tentu tidak selesai dengan 
pembentitukan lembaga saja. kooperasi sampai pada derajat yang Kelembagaan dalam penanganan paling tinggi yaitu collaboration bencana di daerah tetap membutuhkan komitmen dan kesadaran pemerintah daerah terdampak untuk mengelola dan menangani bencana secara bersama sama. Pada proses inilah kemudian letak pentingnya pola hubungan antar lapis pemerintahan, (intergovernmental networks), sebagai salah satu alternatif untuk dapat keluar dari keterbatasan mengelola hubungan yang berbasis hirarkhis dan legal- formal (Pratikno dkk, 2007). Dalam konteks yang lebih luas, Kerjasama pembangunan dan pemanfaatan sumber daya antar daerah dimaksudkan agar dapat mengurangi kesenjangan antar daerah, mengendalikan konflik, meningkatkan pelayanan, pemberdayaan peran serta masyarakat dan meningkatkan efisien dan efektivitas pemanfaatan sumber daya, sehingga terwujud pembangunan yang serasi, selaras dan seimbang sesuai kedudukan, peran dan fungsinya dengan tetap memperhatikan prinsip-prinsip demokrasi, keanekaragaman potensi masing-masing dalam satu manajemen terpadu (Tasmaya, 2007). Dalam literatur lain disebutkan bahwa kerjasama memiliki derajat yang berbeda, mulai dari koordinasi dan (Thomsom, 2001 ; Thomson dan Ferry, 2006). Para ahli pada dasarnya menyetujui bahwa perbedaan terletak dalam kedalaman interaksi, integral, komitmen, dan kompleksitas dimana cooperation terletak pada tingkatan terendah, sedangkan collaboration pada tingkatan yang paling tinggi. (Keban, 2007).

Beberapa keuntungan ketika terjadi hubungan yang baik antar daerah:

a) Pertama, akan mendukung sinergitas antar daerah, seperti: kerjasama dalam penyediaan pelayanan publik, kerjasama pengembangan ekonomi, dan kerjasama pengelolaan lingkungan.

b) Kedua, memperkuat bargaining terhadap pusat, hal ini didasari oleh faktor: kebijakan pemerintah pusat mempengaruhi kapasitas daerah, kebijakan pemerintah pusat mempersempit otonomi daerah.

c) Ketiga, menjadi forum problem solving dan penciptaan opportunity structure untuk pengembangan daerah, bahwa kerjasama yang kuat antar daerah otonom dan memiliki bargaining position yang kuat yang mendominasi sumberdaya dalam kelompok bukan 
untuk menghimpun kekuatan baru untuk menghadapi kekuatan lain, tapi untuk membangun koordinasi dan kolaborasi yang efektif bersama. (William D Coleman dan Anthony pearl, 1999 dalam Pratikno, 2007).

Menurut Ruhyanto dan Hanif dalam Pratikno (2007), bukan perkara yang mudah menggeser paradigma berorganisi, dari organisasi rasional, yang menekankan pada sistem hirarki dan kekuatan regulasi, ke arah intergovernmental networks. Kegagalan seringkali terjadi dikarenakan sulitnya merealisasikan tindakan kolektive (collective actions) untuk memunculkan tujuan bersama (common purpose) dan untuk mengatasi ancaman bersama (common threats). Kegagalan mewujudkan faktor tersebut di atas disinyalir karena kurangnya insentif dan besarnya hambatan dalam melakukan tindakan kolective, disamping juga tujuan kerjasama yang kabur,tidak jelas, tidak menarik juga tiadanya aktor kunci di daerah erta minimnya informasi penting.Dalam perjalanannya, intergovernmental networks menuntut aktor aktor yang terlibat didalamnya untuk menjalankan strategi ke dalam (game manajemen) dan strategi keluar (networks structure). Bagaimana membangun kesadaran bersama akan kebutuhan kerjasama antar daerah dilakukan, dijalankan dalam mekanisme (game manajemen) sedangkan proses tersebut nantinya dibarengi dengan menjalankan strategi keluar (networks structure) seperti aturan atau tatanan yang disepakati bersama dalam jejaring. Dengan adanya kesepakatan yang sudah terbangun, aktor - aktor yang ada dapat merumuskan bersama : strategi pencapaian, pembagian peran, manfaat, tanggung jawab dari masing masing aktor yang terlibat. Serta yang tak kalah pentingnya adalah bagaimana monitoring dan evaluasi dijalankan agar networks yang terbangun tetap on the track dan relevan bagi semua pihak (Pratikno, 2007).

Ketika networks sudah terbangun, tantangan selanjutnya adalah bagaimana strategi dalam mengelola networks tersebut. Salah satu pendekatan yang paling mengemuka adalah pendekatan jaringan (networking). Pendekatan Jaringan mendasarkan pada asumsi bahwa relasi para aktor itu bersifat saling tergantung satu sama lain (interdependence). Dalam makna yang lebih operasional, aktor tidak bakal mampu mencapai tujuan- tujuannya 
tanpa menggunakan sumberdayasumberdaya yang dimiliki oleh aktor lain. Dengan kata lain hubungan ini menghendaki adanya pertukaran sumberdaya- sumberdaya yang ada dalam jaringan (Rhodes dan Marsh, 1992; Rodes, 1997 dalam Pratikno, 2008). Pola jaringan ini semakin lama akan semakin menjadi kompleks jika dilihat dari sumberdaya yang ditukar dan daya tawar para aktornya. Sehingga ketika konsep tersebut diaplikasikan dalam kasus bencana alam daerah, terbuka peluang kerjasama penanganan antara pemerintah kabupaten, kota yang terkena dampak langsung maupun tidak langsung. Kerjasama tersebut tentu dilandasi kesadaran masing- masing pemerintah daerah untuk menyelesaikan konflik secara bersamasama. Beberapa daerah yang kena dampak langsung dan tidak langsung dapat mengimplementasikan konsep kerjasama natar daerah dengan pembagian tugas dan fungsi yang proporsional. Konsep kerjasama sebagaimana dijelaskan oleh Yudhoyono SB (2003), bahwa kerjasama antar daerah terbangun karena adanya kesadaran diantara daerah- daerah yang terlibat kerjasama untuk melakukan sharing of experience, dimana ada ruang bagi daerah untuk saling berbagi pengalaman dalam pengelolaan urusan pemerintahan daerah, terbangunnya kerjasama juga memungkinkan daerah untuk berbagai keuntungan (sharing of benefits) dari arena kerjasama yang dibangun, kerjasama memungkinkan daerah untuk saling berbagi beban (sharing of burdens). Selain dari aspek sharing, kerjasama antar daerah seringkali juga dilandasi oleh semangat bersama dalam menyelesaikan persoalan, atau sebagai kekuatan klektif (Mas'udi, 2006).

Dalam konteks kelembagaan pengelolaan bencana, memang berdasarkan regulasi yang ada, setiap level pemerintahan diharapkan memiliki kelembagaan yang bertanggungjawab dalam menangani bencana (BPBD). Namun faktanya tidak semua pemerintah Kabupaten dan Kota di Indonesia telah menindaklanjuti regulasi tersebut. Terhadap pemerintah daerah yang belum memiliki BPBD, tentu menjadi wajib untuk berkordinasi denga pemrintah propinsi dan bekerjasama dengan pemerintah daerah lainnya. Sedangkan bagi daerah yang sudah memiliki kelembagaan BPBD tentu akan memperkuatdalam 
pengelolaan bencana daerah. Kkesepakatan dan tanggungjawab bersama yang dibangun antara pemerintah kabupaten terdampak tersebut menjadi salah satu alternatif dalam memperkuat pengelolaan dan hubungan antar lapis pemerintahan karena dalam pola network ini, posisi antar aktor yang saling berhubungan bersifat sederajat, tanpa adanya hierarki yang ketat seperti yang diatur dalam kerangka regulasi legal-formal; serta adanya kesepakatan bersama bahwa terdapat saling keterkaitan dan saling ketergantungan antar lapis pemerintahan.

Dalam

intergovernmental networks ini pula kemudian terjadi proses untuk saling memahami dan mengetahui satu sama lain, membagi informasi, mengidentifikasi masalah secara bersama-sama dan merencanakan aksi untuk mengatasi masalah secara bersama-sama.

Tanpa dibarengi dengan adanya alternatif (kerjasama antar daerah) tersebut, maka relasi antar lapis pemerintahan akan mengalami persoalan, seperti adanya resistensi dan pengkotak-kotakan antar satu lapis pemerintahan dengan lapis pemerintahan yang lainnya atau antar satu pemerintah daerah otonom dengan pemerintah daerah otonom lainnya. Dalam konteks inilah sehingga diperlukan kerjasama sebagai solusi alternative dalam pengelolaan hubungan antar tingkatan pemerintah dan tidak lagi mengandalkan pola hubungan yang hirarkis, paksaan, dan legal formal. Hal ini sekaligus untuk mensinergikan hubungan antar lapis pemerintahan dan menghindari berbagai persoalan yang timbul diantaranya adalah adanya resistensi, pengkotak- kotakan dan koordinasi yang rumit. Bahkan keterkaitan antara kewenangan dan dampak akan menjamin akuntabilitas dari penyelenggaraan otonomi daerah. Kerjasama diharapkan menjadi satu jembatan yang dapat mengubah potensi konflik kepentingan antar daerah menjadi sebuah potensi pembangunan yang saling menguntungkan.

\section{Kesimpulan}

Konsep KAD selain untuk mengoptimalkan potensi daerahnya, Kerjasama Antar Daerah (KAD) dapat menjadi salah satu alternatif inovasi/konsep yang didasarkan pada pertimbangan efisiensi dan efektivitas, 
sinergis dan pemecahan masalah bersama yang saling menguntungkan terutama dalam bidang-bidang yang menyangkut kepentingan lintas wilayah. Hasil diskursus kerjasama antar daerah dalam peanganganan bencana memberikan berbagai masukan berharga dalam

pengembangan pemikiran dan solusi alternatif penganan bencana di daerah. beberapa hal penting tersebut dapat disimpulkan sebagaimana berikut:

a) Implementasi dari konsep intergovermental dalam penanganan bencana di daerah memiliki relevansi yang kuat. Bahwa kerjasama antar daerah terbangun bukan hanya karena motif berbagi keuntungan (sharing of benefits), namun, dari arena kerjasama dibangun kesadaran diantara daerahdaerah yang terlibat melakukan sharing of experience, dimana ada ruang bagi daerah untuk saling berbagi pengalaman dalam pengelolaan urusan pemerintahan daerah, selain itu, kerjasama memungkinkan daerah untuk saling berbagi beban (sharing of burdens).

b) Namun disisi lain, masih perhatian Pemerintah Daerah terhadap model Penanggulangan Bencana secara bersama sama masih rendah dan karena masih egoisme masing masing daerah.

c) Perubahan kelembagaan dalam penanganan bencana sudah dilakukan dari responsif-kuratif menjadi antisipatifpreventif melalui (BPBD) namun belum ditindaklanjuti dengan ketentuan teknis.

d) Intergovermental dalam penanganan bencana berpeluang mengatasi ketiadaan regulasi teknis dan pembagian tugas antar level pemerintahan. Misalnya tentang logistik bencana, distribusi logistik pada masa tanggap darurat bencana.

\section{Daftar Pustaka}

Sadat, A. (2016). Efektivitas Kineria Badan Penanggulangan Bencana Daerah Dalam Pengurangan Resiko Bencana Di Kota Baubau. Iurnal Ilmu Pemerintahan: Kaiian Ilmu Pemerintahan dan Politik Daerah, 1(1), 1-21.

Henry, N. 1995. Public Administration and Public Affairs. Sixth Edition. Englewood Cliffs, N.J. : PrenticeHall.

Rosen, E.D. 1993. Improving Public Sector Productivity: Concept and Practice. London: Sage Publications, International Educational and Professional Publisher.

Kickert, Walter J.M., Erik-Hans Klijn, dan Joop F.M. Koppenjan, 1997, MANAGING COMPLEX NETWORK, Sage Publication Ltd., London

Nurcholis, Hanif, 2007, Teori dan Praktik Pemerintahan dan Otonomi Daerah 
Pratikno, 2007, KERJASAMA ANTAR DAERAH: Kompleksitas dan Tawaran Format Kelembagaan

Pratikno, 2008, MANAJEMEN JARINGAN DALAM PERSPEKTIF STRUKTURISASI, Jurnal Kebijakan dan Administrasi Publik@ Magister Admnistrasi Publik UGM, Volume 12 Nomor 1 (Mei 2008)

Ruhyanto, Arie., Hanif Hasrul, 2007 Kerjasama antar daerah sebagai jejaring Interorganisasional

Moleong, Lexy J. 2002. Metode Penelitian Kualitatif. Remaja Rosdakarya: Bandung.

$\mathrm{Nu}$ Nugroho, Riant. 2003. Kebijakan Publik, Formulasi, Implementasi, dan Evaluasi, PT. Elek Media
Komputindo, Kelompok Gramedia: Jakarta.

Van Meter, D.S and C.E Van Horn., 1975. The Policy Implementation Process : A Conceptual Framework, Administration and Society

Sugiono, 2003. Metode Penelitian Administrasi, Alfa Beta, Bandung Undang-undang Nomor 33 Tahun 2004 tentang Perimbangan Keuangan antara Pemerintah Pusat dan Pemerintah Daerah.

Isbandono, Prasetyo, dkk., 2015. Kajian Kelembagaan dan Regulasi Penanggulangan Bencana 